\title{
The Potential of Targeting Ribosome Biogenesis in High-Grade Serous Ovarian Cancer
}

\author{
Shunfei Yan ${ }^{1,2,+}$, Daniel Frank ${ }^{1,3,+}$, Jinbae Son ${ }^{1,2}$, Katherine M. Hannan ${ }^{3,4}$, \\ Ross D. Hannan ${ }^{1,2,3,4,5,6}$, Keefe T. Chan ${ }^{1}$, Richard B. Pearson 1,2,3,5,* and Elaine Sanij 1,7,* \\ 1 Research Division, Peter MacCallum Cancer Centre, Melbourne, VIC 3000, Australia; \\ Shunfei.yan@petermac.org (S.Y.); dfrank@student.unimelb.edu.au (D.F.); jinbae.son@petermac.org (J.S.); \\ ross.hannan@anu.edu.au (R.D.H.); keefe.chan@petermac.org (K.T.C.) \\ 2 Sir Peter MacCallum Department of Oncology, The University of Melbourne, Parkville, VIC 3010, Australia \\ 3 Department of Biochemistry and Molecular Biology, University of Melbourne, Parkville, VIC 3010, \\ Australia; kate.hannan@anu.edu.au \\ 4 The John Curtin School of Medical Research, The Australian National University, Canberra, \\ ACT 2601, Australia \\ 5 Department of Biochemistry and Molecular Biology, Monash University, Clayton, VIC 3168, Australia \\ 6 School of Biomedical Sciences, University of Queensland, Brisbane, QLD 4072, Australia \\ 7 Department of Pathology, University of Melbourne, Parkville, VIC 3010, Australia \\ * Correspondence: rick.pearson@petermac.org (R.B.P.); elaine.sanij@petermac.org (E.S.); \\ Tel.: +61-3-8559-5473 (R.B.P.); +61-3-8559-5279 (E.S.) \\ + These authors contributed equally to the work.
}

Academic Editor: Kwong-Kwok Wong

Received: 20 December 2016; Accepted: 12 January 2017; Published: 20 January 2017

\begin{abstract}
Overall survival for patients with ovarian cancer (OC) has shown little improvement for decades meaning new therapeutic options are critical. OC comprises multiple histological subtypes, of which the most common and aggressive subtype is high-grade serous ovarian cancer (HGSOC). HGSOC is characterized by genomic structural variations with relatively few recurrent somatic mutations or dominantly acting oncogenes that can be targeted for the development of novel therapies. However, deregulation of pathways controlling homologous recombination (HR) and ribosome biogenesis has been observed in a high proportion of HGSOC, raising the possibility that targeting these basic cellular processes may provide improved patient outcomes. The poly (ADP-ribose) polymerase (PARP) inhibitor olaparib has been approved to treat women with defects in HR due to germline $B R C A$ mutations. Recent evidence demonstrated the efficacy of targeting ribosome biogenesis with the specific inhibitor of ribosomal RNA synthesis, CX-5461 in v-myc avian myelocytomatosis viral oncogene homolog (MYC)-driven haematological and prostate cancers. CX-5461 has now progressed to a phase I clinical trial in patients with haematological malignancies and phase I/II trial in breast cancer. Here we review the currently available targeted therapies for HGSOC and discuss the potential of targeting ribosome biogenesis as a novel therapeutic approach against HGSOC.
\end{abstract}

Keywords: high-grade serous carcinoma; ribosome biogenesis; Pol I; CX-5461; homologous recombination

\section{Introduction}

Ovarian cancer (OC) is the seventh most common cancer in females worldwide (8th overall), with over 239,000 new cases diagnosed every year. It is one of the most lethal gynecological cancers causing more than 152,000 deaths worldwide per year [1]. OC patients typically present with advanced disease at diagnosis due to the location of the disease and the lack of symptoms in early 
stages [2]. The five-year survival rate of $46.2 \%$ has not improved over the past three decades in contrast to other cancers such as breast cancer, which has improved from $74.9 \%$ to $89.7 \%$ [3]. Clearly, identification of new therapeutic strategies and methods of early detection are essential to achieve better patient outcome.

OC is a highly heterogeneous disease characterized by distinct clinical features including grade, histology, molecular alterations and response to therapy. OC is classified into three main types, namely epithelial (EOC), germ cell and stromal. EOC accounts for $>90 \%$ of all OC cases with the majority appearing to originate from the distal fallopian tube [4,5]. Non-epithelial cancers of the ovary arising from the germ and stromal cell layers are rare, heterogeneous and have proved difficult to study [6].

EOC tumours are classified into two distinct groups, low-grade (type I) and high-grade (type II) tumours, with unique histological, clinical and molecular profiles [7-11] (Table 1). Low-grade serous (LGSOC), clear cell, endometrioid and mucinous ovarian cancers are categorized as type I since these tumours are confined to the ovary and are not invasive. While type II tumours comprise high-grade serous OC (HGSOC), high-grade endometrioid, undifferentiated carcinoma and carcinosarcomas. HGSOC is the most aggressive subtype and accounts for approximately $70 \%$ of all EOC [12], and is by far the most studied OC.

Table 1. Histotypes and genetic alterations of OC.

\begin{tabular}{|c|c|c|c|c|c|}
\hline \multicolumn{6}{|c|}{ Epithelial Ovarian Cancer } \\
\hline Subtypes & $\begin{array}{c}\text { High-Grade Serous } \\
\text { Ovarian Cancer } \\
\text { (Type II) }\end{array}$ & $\begin{array}{c}\text { Low-Grade Serous } \\
\text { Ovarian Cancer } \\
\text { (Type I) }\end{array}$ & $\begin{array}{c}\text { Clear Cell } \\
\text { Ovarian Cancer } \\
\text { (Type I) }\end{array}$ & $\begin{array}{c}\text { Endometrioid } \\
\text { Ovarian Cancer } \\
\text { (Type I) }\end{array}$ & $\begin{array}{c}\text { Mucinous } \\
\text { Ovarian } \\
\text { Cancer (Type I) }\end{array}$ \\
\hline $\begin{array}{l}\text { Genome } \\
\text { Instability }\end{array}$ & High & Low & Low & Low & Low \\
\hline \multirow[b]{3}{*}{$\begin{array}{l}\text { Frequent Genetic } \\
\text { Alternations }\end{array}$} & TP53 mut (>90\%) & TP53 wt & TP53 wt & TP53 wt & TP53 wt \\
\hline & $\begin{array}{c}\text { BRCA1/2( 15\%) HR } \\
\text { deficiency (up to } 50 \%)\end{array}$ & Uncommon & Uncommon & Uncommon & Uncommon \\
\hline & $\begin{array}{c}\text { PI3K pathway } \\
(P I K 3 C A, R I C T O R, \\
A K T, R A P T O R, P T E N) \\
\text { RAS pathway }(K R A S, \\
\text { MAPK, ERBB2) } \\
\text { IGF-1R, EGFR, } \\
\text { KIT, CNNE }\end{array}$ & $\begin{array}{c}\text { RAS pathway } \\
(K R A S, B R A F) \\
\text { HER2 }\end{array}$ & $\begin{array}{l}\text { PI3K pathway } \\
(P I K 3 C A) \text { MET }\end{array}$ & $\begin{array}{c}\text { PI3K pathway } \\
(P I K 3 C A, P T E N) \\
\boldsymbol{\beta} \text {-catenin }\end{array}$ & $\begin{array}{c}\text { RAS pathway } \\
(K R A S / B R A F) \\
\text { HER2 }\end{array}$ \\
\hline $\begin{array}{c}\text { 5-year } \\
\text { Survival Rate }\end{array}$ & $\sim 40 \%$ & $\sim 70 \%$ & $>70 \%$ & $>90 \%$ & $\sim 78 \%$ \\
\hline
\end{tabular}

In addition to histological subtype, OC has been classified by different criteria. For example, Bowtell and colleagues grouped serous and endometrioid OC into six molecular subtypes (C1-C6) based on gene expression patterns including stromal, mesenchymal, immune, cell motility, cell surface/secreted markers, $\beta$ catenin/T cell factor (TCF) /lymphoid enhancer factor (LEF) transcriptional targets and mitogen-activated protein kinase (MAPK) pathway activation signatures [13]. These molecular profiles are associated with different clinical outcomes and micro-environmental features such as immune and stromal cell activation [11]. Furthermore, Mori and colleagues identified five distinct molecular subtypes of EOC (Epi-A, Epi-B, Mes, Stem-A and Stem-B) that exhibited distinct clinical pathological characteristics and rates of overall survival. These subtypes show different enrichment in fibrinolysis, metastasis, extracellular matrix remodeling, TGF $\beta$ and chromatin modification processes and offer novel diagnostic and therapeutic strategies to target specific subtypes of EOC [14]. In the clinic, however, histological subtypes remain the conventional classification method for diagnosis and treatment.

Indeed, emerging knowledge of the underlying molecular alterations in EOC could allow for more personalized diagnostic and therapeutic strategies. PIK3CA, BRAF and KRAS somatic mutations are relatively common in type I tumours, with each subtype exhibiting distinct molecular profiles (Table 1). In contrast, HGSOCs display high levels of genomic instability with few common mutations, other than the tumour suppressor gene TP53, which is altered in over $90 \%$ of HGSOC cases $[8,15]$. 
Approximately, $50 \%$ of HGSOC is characterized by frequent genetic and epigenetic alteration of the Fanconi anemia/breast-related cancer antigens (BRCA) homologous recombination (HR) DNA repair pathway, most commonly affecting the $B R C A 1$ and $B R C A 2$ genes $(15 \%-20 \%)[8,16-18]$. Furthermore, the phosphatidylinositol-4,5-bisphosphate 3-kinase (PI3K) and retrovirus-associated DNA sequences (RAS) signalling pathways are altered in $45 \%$ of HGSOC cases due to loss or amplifications of genes involved in these signalling networks [8]. While most HGSOC have an initial favourable response to platinum-based therapy, this is followed by cycles of relapse and the development of acquired resistance to chemotherapy [11]. Thus, identification of new therapeutic strategies is essential to better treat this disease at diagnosis. Undoubtedly, more tailored treatments based on the molecular characteristics of the OC subtypes underpin the next phase of personalized medicine in OC.

\section{Current Diagnostic and Standard Therapeutic Approach for High-Grade Serous Ovarian Cancer (HGSOC)}

At present, there are no proven effective screening strategies for early diagnosis of HGSOC and $\mathrm{OC}$ in general, although a few biomarkers have been introduced to the clinic. One of the most widely studied biomarkers for HGSOC is serum levels of cancer antigen 125 (CA-125), which has been shown to correlate with disease stage and response to treatment [19]. However, a significant proportion $(\sim 20 \%)$ of early stage OC do not express the CA-125 antigen, thus tests for this marker are often used in combination with other tests, such as transvaginal sonography [20]. Furthermore, the specificity for detecting OC alone is poor $[19,21,22]$. False-negative diagnostic results are frequent since HGSOC may be invasive despite small tumour volume. Thus, it is important to continue to identify and validate additional biomarkers to achieve better detection of early-stage ovarian cancer.

The standard therapeutic approach for treating HGSOC relies on debulking surgery followed by subsequent treatment with a combination of platinum-based (e.g., carboplatin and cisplatin) and taxane-based (e.g., paclitaxel) drugs. Platinum-based compounds induce DNA adducts that cause DNA damage and trigger cell death $[23,24]$. In contrast, paclitaxel-based compounds inhibit microtubule dynamics to block mitosis, resulting in cell death [25]. Approximately $90 \%$ of patients with stage I OC (cancer confined to ovaries) show complete response to first-line treatment [26]. Patients with $B R C A 1 / 2$ mutated cancers have better outcome following platinum-based chemotherapy than their non- $B R C A 1 / 2$ mutated counterparts as their cells are incapable of repairing DNA double-strand breaks (DSBs), leading to sensitization to DNA-damaging agents $[27,28]$. Unfortunately, however, $\sim 80 \%$ of patients present with advanced disease whereby tumours have metastasized to other non-ovarian tissues, which is associated with a significantly reduced response to first-line treatment [29,30]. Moreover, cases of relapse and development of chemoresistance are frequently observed $[29,30]$. Thus far, mechanisms of resistance include mutations that restore the original function of defective $B R C A 1 / 2$, loss of $B R C A 1$ promoter methylation, CCNE1 amplification and alteration in molecular subtype [31-34].

Several salvage regimens exist for platinum refractory cases including Topoisomerase I inhibitors (e.g., Topotecan), Topoisomerase II inhibitors (Etoposide or Doxorubicin), microtubule inhibitors (Vinorelbine), alkylating reagents (Altretamine, Ifosfamide), anti-metabolites (Gemcitabine), estrogen receptor (ER) inhibitors (Tamoxifen, in ER-positive tumours) and epidermal growth factor receptor 2 (HER2) inhibitors (Herceptin, in HER2-positive tumours). These drugs can either be used as single agents or in combination with other drugs [35,36]. However, the response rate is very low and average survival times are extremely short [2]. Indeed in April 2016, the National Institute for Health and Care Excellence (NICE) published guidance for five OC drugs, recommending two and rejecting three. In particular, the guidance recommended paclitaxel and pegylated liposomal doxorubicin hydrochloride (PLDH) for treating recurrent OC. Paclitaxel and PLDH can be used as monotherapy, or in combination with platinum.

The rapid advance of molecular discoveries in OC has offered exciting opportunities for targeted therapies. These include drugs that target the tumour vasculature as well as those that inhibit DNA repair processes or the PI3K and RAS growth signalling pathways. One of the first promising targeted 
agents is bevacizumab, a recombinant humanized monoclonal IgG antibody that targets vascular endothelial growth factor (VEGF) A, which has now been approved in stage IIIb recurrent platinum sensitive and refractory OC $[37,38]$. Although clinical trials showed remarkable improvement in progression-free survival, this did not translate to an overall survival benefit $[39,40]$.

The identification of synthetic lethality using the poly (ADP-ribose) polymerase (PARP) inhibitors (PARPi) in BRCA1/2-mutant ovarian cancer cell lines [41] led to the development of one of the most exciting new classes of targeted therapy in HGSOC [42]. The PARP inhibitor olaparib has been approved as monotherapy for women with germline BRCA1/2 mutations [43]. PARP inhibitors silence the PARP1/2 proteins, which are essential for sensing genotoxic insults, such as DNA single-strand breaks (SSBs) and DSBs and are involved in a number of DNA repair pathways including base-excision repair (BER) and HR [44]. These inhibitors show efficacy in cancer cells with HR deficiency (HRD) including non-BRCA1/2 mutant tumours that carry mutations in genes involved in the HR pathway, since the accumulation of damaged DNA eventually leads to cell death. However, mechanisms leading to HR restoration have been implicated in conferring resistance to PARPi [44]. More recently, results in trials using the PARP inhibitor niraparib showed positive benefit in OC patients regardless of germline BRAC1/2 mutations or HRD status, suggesting that HRD status may not be an effective biomarker of sensitivity to PARP inhibitors [45].

Other compounds in clinical trials showing promise include APR-246 (also known as PRIMA- ${ }^{\text {MET }}$ ), which reactivates mutant $\mathrm{p} 53$ by facilitating its refolding to wild-type conformation leading to induction of apoptosis in cancer cells [46,47]. Furthermore, recent findings demonstrated the ability of APR-246 to resensitize p53-mutant OC to cisplatin, suggesting significant synergy, which may dramatically improve the outcome of HGSOC [48]. At this stage, the Phase Ib/II study of APR-246 in combination with platinum-based therapy in OC is ongoing.

Other targeted therapies in OC including targeting the oncogenic PI3K/mammalian target of rapamycin complex 1 (mTORC1) and RAS pathways remain less effective due to the complexity and redundancy of these pathways [49].

\section{Deregulation of Growth Signalling Pathways Upstream of Ribosome Biogenesis in HGSOC}

Several signalling pathways central to normal control of cell growth and proliferation are frequently dysregulated in OC. In particular, activation of the PI3K/AKT/mTORC1 and RAS/MAPK signalling pathways and the c-MYC ( $\mathrm{v}$-myc avian myelocytomatosis viral oncogene homolog) proto-oncogene "super" growth regulatory network is prevalent among the major histological subtypes (Figure 1). It is now well accepted that therapeutic targeting of the PI3K/mTOR pathway alone is not sufficient for robust clinical responses in many tumour types, due to feedback loops and compensatory activation of RAS signalling [49]. Indeed, recent in vitro and in vivo pre-clinical studies demonstrate efficacy with PF502 and PD901 inhibitors, which target the PI3K/mTOR and RAS/MAPK networks respectively, to achieve significant reduction in tumour burden and improvement in overall survival [50,51]. Hence, combinatorial targeting of multiple growth signalling pathways and/or processes required for cell growth and proliferation downstream of these pathways such as ribosome biogenesis may prove effective in OC treatment. Ultimately, these pathways converge to regulate ribosome biogenesis and protein synthesis. Over the last five years, targeting ribosome biogenesis has emerged as a novel approach for cancer therapy. In this section, we review the signalling pathways upstream of ribosome biogenesis that are aberrantly regulated in OC with a primary focus on HGSOC. 


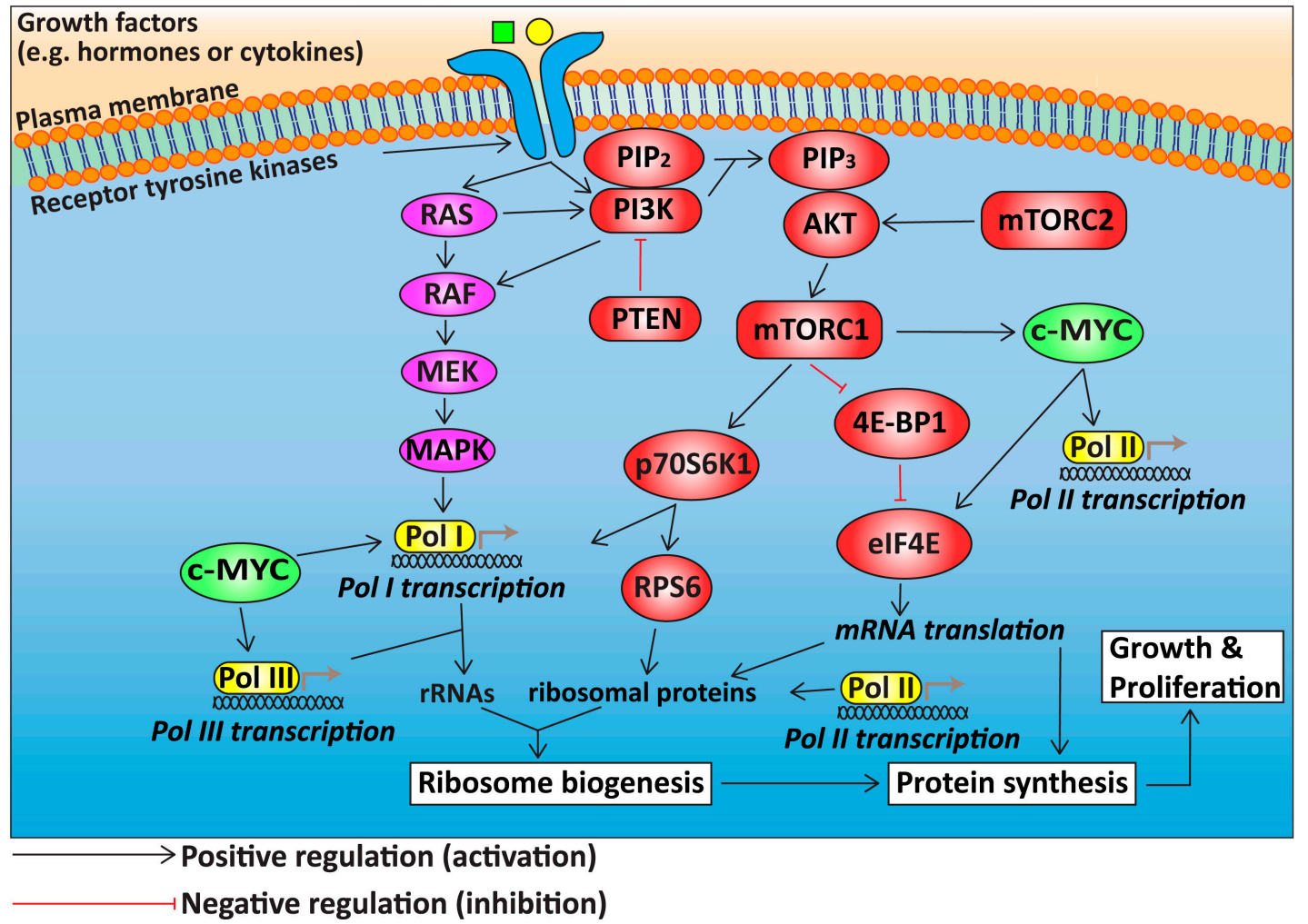

Figure 1. The phosphatidylinositol-3-kinase/mammalian target of rapamycin (PI3K/mTOR), retrovirus-associated DNA sequences/mitogen activated protein kinase (RAS/MAPK) pathways and c-MYC are master regulators of cell growth and proliferation. The PI3K/mTOR and RAS/MAPK signalling, and c-MYC transcription pathways are three major oncogenic drivers of cell growth and proliferation. They form a "super" network to regulate ribosome biogenesis and protein translation. The signalling cascades are predominantly initiated upon growth factor stimulation through receptor tyrosine kinases. Growth factors are represented by the green square and yellow circle. Activation of PI3K leads to induction of downstream effects mediated by the AKT oncoprotein including the activation of mTORC1 and subsequent phosphorylation of its downstream effectors, 4E-BP1 and p70S6K1. Concomitantly, the RAS signalling pathway and the c-MYC transcription factor contribute to the control of ribosome biogenesis via modulating the synthesis of rRNAs by Pol I. Moreover, c-MYC also exerts its positive regulatory effects on Pol II, Pol III, and eIF4E. Together, these three key pathways promote ribosome synthesis and protein synthesis and thus cell growth. (PI3K: phosphatidylinositol-3-kinase; mTORC: mammalian target of rapamycin complex; PTEN: phosphatase and tensin homolog; PIP2: phosphatidylinositol-4,5-bisphosphate; PIP3: phosphatidylinositol-3,4,5-triphosphate; p70S6K1: p70 S6 kinase 1; 4E-BP1: eukaryotic initiation factor 4E-binding protein 1; eIF4E: eukaryotic translation initiation factor 4E; rRNA: ribosomal RNA; Pol I: RNA Polymerase I; Pol II: RNA Polymerase II; Pol III: RNA Polymerase III). The grey arrows denote ongoing transcription.

\subsection{The PI3K/AKT/mTOR Signalling Pathway in HGSOC}

Constitutive activation of the PI3K/AKT/mTORC1 pathway in OC occurs through activating mutations of PI3K-related genes, amplification of AKT signalling or inactivating mutations of phosphatase and tensin homolog deleted on chromosome TEN (PTEN) [8]. This signalling cascade controls many of the processes that are important for cancer development, e.g., the cell cycle, cell survival, metabolism, motility, angiogenesis, chemoresistance, and genomic instability [52].

Mutations of genes in the PI3K/AKT/mTOR pathway are rare in HGSOC. Instead, HGSOC is associated with frequent oncogenic copy number amplifications in PIK3CA (23\%), RICTOR (6\%), 
RAPTOR (4\%), AKT1/2/3 (15\%) and oncogenic loss of PTEN in 7\% of cases. However, assessment of PI3K pathway activation by immunohistochemical analyses of phosphorylated/ activated AKT and mTOR identified pathway activation in approximately $50 \%$ of HGSOC [53].

In contrast to HGSOC, aberrations in the PI3K pathway are more prevalent in the rare subtypes of OC. A total of $20 \%$ of endometrioid and $35 \%$ of clear cell OC have PIK3CA gene mutations, whereas PTEN loss-of-function mutations occur in $20 \%$ of endometrioid OC $[8,49,54,55]$. Activation of the PI3K pathway in low-grade serous ovarian cancer (LGSOC) occurs through expression of insulin-like growth factor receptor (IGF-R) [56]. Single-agent studies of PI3K pathway-directed agents targeting only one node along the pathway have demonstrated limited success in OC [57]. This is due, at least in part, to feedback loops such as compensatory activation of AKT observed after mTORC1 inhibition and crosstalk between signalling pathways including the RAS/MAPK pathway [58].

\subsection{RAS/RAF/MEK/MAPK Signalling in HGSOC}

The RAS pathway plays a critical role in the regulation of cell survival, proliferation and motility. Strikingly, gene mutations in the RAS pathway components, including KRAS, BRAF, MEK or ERBB2 (also known as HER2), encoding the upstream regulators of MAPK, are observed in more than $68 \%$ of LGSOC [9]. In HGSOC, activation of this pathway occurs through oncogenic amplification of MAPK (25\% of cases), KRAS (11\%), ERBB2 (3\%), and ERBB3 (4\%) [8]. Endometrioid and mucinous OC also have a high prevalence of KRAS mutations, up to $30 \%$ [59] and $60 \%$ of cases, respectively. ERBB2 amplification also occurs in a small proportion of mucinous OC cases [60]. Clinically, the MAPK/ERK kinase (MEK) inhibitor selumetinib has been explored in LGSOC with promising activity and may offer an advantage over or in combination with chemotherapy [61,62]. On the other hand, a phase II trial of selumetinib in recurrent endometrioid carcinoma achieved modest results [63]. In light of potential resistance to MEK being mediated via the PI3K/AKT pathway, early data from two studies investigating the combination of PI3K and MEK inhibitors in selected OC patients based on genomic alterations in the PI3K and RAS signalling pathway support further investigation of this combination with close monitoring of cumulative toxicities $[49,64]$.

\section{3. $c-M Y C$ in $H G S O C$}

The c-MYC transcription factor plays an essential role in regulating many cellular processes including cell growth, cell-cycle progression, differentiation, and apoptosis. Frequent focal amplification of chromosome $8 \mathrm{q} 24$ which encodes eight genes, one of which is $c-M Y C$, occurs in up to $80 \%$ of HGSOC [8]. In non-transformed cells, MYC expression is typically low and tightly regulated. Whilst mutations in the $M Y C$ gene have been identified, the critical determinant of its oncogenic potential is its overexpression, which contributes to global increases in gene expression [65]. Furthermore, c-MYC expression levels have been associated with chemoresistance [66].

Central to MYC's ability to drive cell growth and proliferation is its role in promoting ribosome synthesis [67-69]. c-MYC controls ribosome biogenesis at multiple levels by coordinating the activity of all three RNA polymerases to produce the major constituents of ribosome particles (described in more details in Section 4). c-MYC facilitates the recruitment of RNA polymerase I (Pol I) to ribosomal DNA (rDNA) promoters, and promotes the synthesis of $47 \mathrm{~S}$ ribosomal RNA (rRNA) precursor, which is processed to form the $18 \mathrm{~S}, 5.8 \mathrm{~S}$, and $28 \mathrm{~S}$ mature rRNAs [70-72]. In addition, c-MYC enhances Pol I transcription by increasing the pool of available core transcription factors, including the upstream binding factor (UBF), selectivity factor 1 (SL-1) and RRN3 [73]. Furthermore, c-MYC promotes Pol II transcription of mRNAs encoding ribosomal proteins (RPs) and Pol III-mediated transcription of the $5 S$ rRNA [69], as well as translation initiation by eukaryotic translation initiation factor 4E (eIF4E) [74]. Thus, c-MYC is a master regulator of ribosome biogenesis and protein synthesis [75].

Furthermore, the PI3K/mTOR and RAS/MAPK signalling cascades cooperate with the c-MYC transcription network to enhance ribosome biogenesis and protein translation (Figure 1) [76]. Upon activation by mitogenic signals, $\mathrm{PI} 3 \mathrm{~K} / \mathrm{AKT} / \mathrm{mTORC} 1$ signalling modulates the translation capacity 
and efficiency of ribosomes and induce transient upregulation of protein synthesis [76-81]. The RAS signalling cascade cooperates with c-MYC via enhancing the activity of the Pol I core transcription factors through phosphorylation by multiple kinases including MAPK, RSK and JNK [82,83]. Given that this "super" network of PI3K, RAS and MYC nodes, that controls ribosome biogenesis, is frequently deregulated in $\mathrm{OC}$, targeting ribosome biogenesis may prove effective in OC treatment and can possibly overcome resistance mechanisms that allow compensatory activation of various steps in this network.

\section{Targeting Ribosome Biogenesis Is a Novel Approach for Cancer Treatment}

Synthesis of the mature $80 \mathrm{~S}$ eukaryotic ribosomes is a tightly regulated multistep process, involving the concerted roles of Pol I, Pol II, and Pol III [84,85] (Figure 2) and utilizing at least $80 \%$ of the metabolic energy of proliferating cells [86]. The Pol I and Pol III complexes are responsible for producing the nucleic acid backbone of the mature ribosomes. Pol I transcribes the rRNA genes to produce the $47 \mathrm{~S}$ pre-rRNA in the nucleolus, which is then processed to yield the $18 \mathrm{~S}, 5.8 \mathrm{~S}$ and $28 \mathrm{~S}$ mature rRNA molecules [87], whereas Pol III transcribes the 5S rRNA [88]. The remainder of the ribosome is made up of approximately 78 proteins, whose mRNAs are transcribed by Pol II and, upon translation, are transported to the nucleoli and assembled with rRNAs to form the 40S and 60S ribosomal subunits, before being exported to the cytoplasm to form functional ribosomes $[84,85]$.

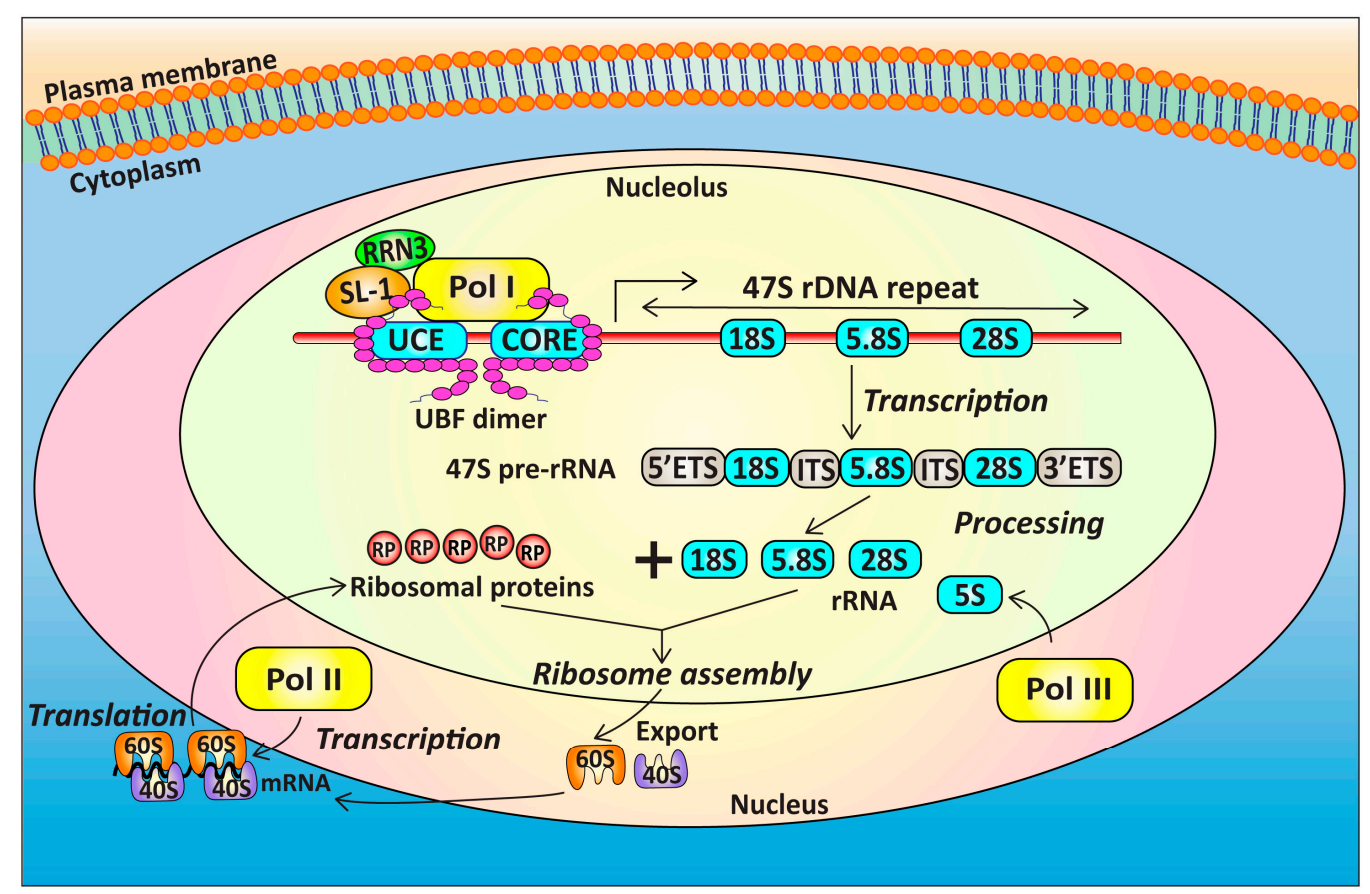

Figure 2. Ribosome biogenesis requires the concerted actions of Pol I, Pol II, and Pol III. The mature ribosome subunits consist of RPs and rRNAs. The Pol I-related transcription factors UBF and SL-1 interact with the rDNA promoter at the UCE and Core elements and form the preinitiation complex. Transcriptionally competent Pol I complex, defined by the presence of RRN3, is then recruited to transcribe the $47 \mathrm{~S}$ rRNA precursor, which is processed to produce the 18S, 5.8S, and $28 \mathrm{~S}$ mature rRNAs. These rRNAs, together with 5S rRNA transcribed by Pol III, and the RPs transcribed by Pol II are then assembled in the nucleolus to form the $40 \mathrm{~S}$ and $60 \mathrm{~S}$ ribosomal subunits. Upon export from the nucleolus to the cytoplasm, the fully functional $80 \mathrm{~S}$ ribosome is then formed. (RP: ribosomal proteins; rRNA: ribosomal RNA; Pol I: RNA Polymerase I; Pol II: RNA Polymerase II; Pol III: RNA Polymerase III; PIC: Pol I pre-initiation complex; UCE: upstream control element; CORE: core promoter element; UBF: upstream binding factor; SL-1: selectivity factor 1; ETS: external transcribed spacer, ITS: internal transcribed spacer). 
Cancer cell proliferation is supported by elevated protein synthesis mediated by increased rates of ribosome biogenesis and accelerated Pol I transcription is associated with cancer development [89-96]. As such, impairing ribosome biogenesis may serve as a therapeutic approach in treating various forms of malignancy. Indeed, many cancer therapeutic drugs have been proposed to elicit their anti-tumour activity via inhibiting ribosome biogenesis [97-99]. Importantly, targeting Pol I transcription is now considered a promising target for cancer therapy [100]. This therapeutic approach may prove effective against HGSOC considering that deregulation of pathways upstream of Pol I transcription is a common event in HGSOC.

\subsection{Targeting Pol I Transcription}

Until 2009, only Dactinomycin (also called Actinomycin D), a naturally occurring polypeptide antibiotic that intercalates GC-rich regions of DNA, was known to be highly selective for the rRNA genes at low concentrations $(5 \mathrm{nM})$ by preventing the elongation stage of Pol I transcription. In addition, the platinum compound cisplatin and inhibitors of Topoisomerase I activity (camptothecin, Irinotecan and Topotecan) inhibit Pol I transcription with some degree of specificity (reviewed in $[101,102])$. However, the degree to which inhibition of Pol I transcription contributes to their therapeutic efficacy is not established [99]. BMH-21, a DNA intercalator with binding preference to GC sequences, has demonstrated potent effects on rDNA transcription. BMH-1 can also target RPA194 (a core Pol I holoenzyme subunit) for proteasomal degradation leading to disassembly of the Pol I complex and dissociation from the rDNA, although this event is secondary to Pol I transcription inhibition [103]. BMH-21 achieved potent reduction of tumour growth in human melanoma and colorectal carcinoma xenograft models in vivo. Furthermore, the specific small molecule inhibitor of Pol I transcription CX-5461 has proved impressive as a novel anti-cancer agent in heamatological and prostate cancers [95,96,104-106]. Indeed, CX-5461 is the first specific inhibitor of Pol I transcription to enter the clinic, having progressed into "first in class" phase I clinical trials in patients with advanced haematological malignancies (Peter Mac, Melbourne, Australia) and phase I/II in breast cancer (Vancouver, BC, Canada).

\subsection{Cellular Response to CX-5461}

CX-5461 inhibits Pol I transcription by preventing SL-1 from interacting with the rDNA promoter resulting in inhibition of Pol I recruitment and transcription initiation [104] (Figure 3). CX-5461 induces p53-dependent and independent anti-proliferative responses including cell-cycle arrest, apoptosis, or senescence in various cancer cell lines $[104,107]$. This includes activation of the nucleolar stress response, which is a surveillance mechanism that coordinates cellular response to deregulation of ribosome biogenesis $[101,104,108]$. Central to this response is the activation of p53 via the release of free RPs from the nucleolus, in particular the RPL5/RPL11/5S rRNA complex [109,110], which binds and inactivates the E3 ubiquitin ligase murine double minute 2 (MDM2) [111], thus preventing proteasomal degradation of p53 [112]. The outcomes of p53 activation are diverse, ranging from DNA repair, transient cell-cycle arrest, apoptosis, permanent cell-cycle arrest or senescence [113,114] (Figure 3). CX-5461 selectively induces p53-mediated apoptosis of MYC-driven B-lymphoma cells in vivo with minimal effects on wild type cells of the same lineage $[96,104,105]$. The dependence of MYC-driven B-cell lymphoma on high rates of Pol I transcription sensitizes these cells to CX-5461 while normal cells can tolerate reductions in rRNA synthesis without induction of cell death [96,104]. A recent study demonstrated that cells with a high rate of ribosome biogenesis exhibit high levels of p53 protein stabilization upon treatment with CX-5461, due to more RPs being available to bind MDM2 thus preventing p53 degradation [115].

Furthermore, studies in acute lymphoblastic leukemia (ALL) suggested that CX-5461 treatment of p53-mutant ALL cells leads to G2 phase arrest and induction of apoptosis via the ataxia telangiectasia mutated (ATM) / ataxia telangiectasia and Rad3-related protein (ATR) pathways [116,117] (Figure 3). More recently, CX-5461 was shown to induce p53-independent, ATM/ATR-mediated G1 and G2 
cell-cycle arrest, and senescence in telomerase reverse transcriptase (TERT)-immortalized human fibroblasts [107]. Acute treatment with CX-5461 (1 h) was shown to induce chromatin defects at the rDNA associated with depletion of Pol I binding across the transcribed region, leading to activation of DNA damage signalling in the absence of global DNA damage [96]. Since the therapeutic efficacy of CX-5461 is not restricted to cellular p53 status, CX-5461 has the potential for treating HGSOC either as a single agent or in combination therapies.

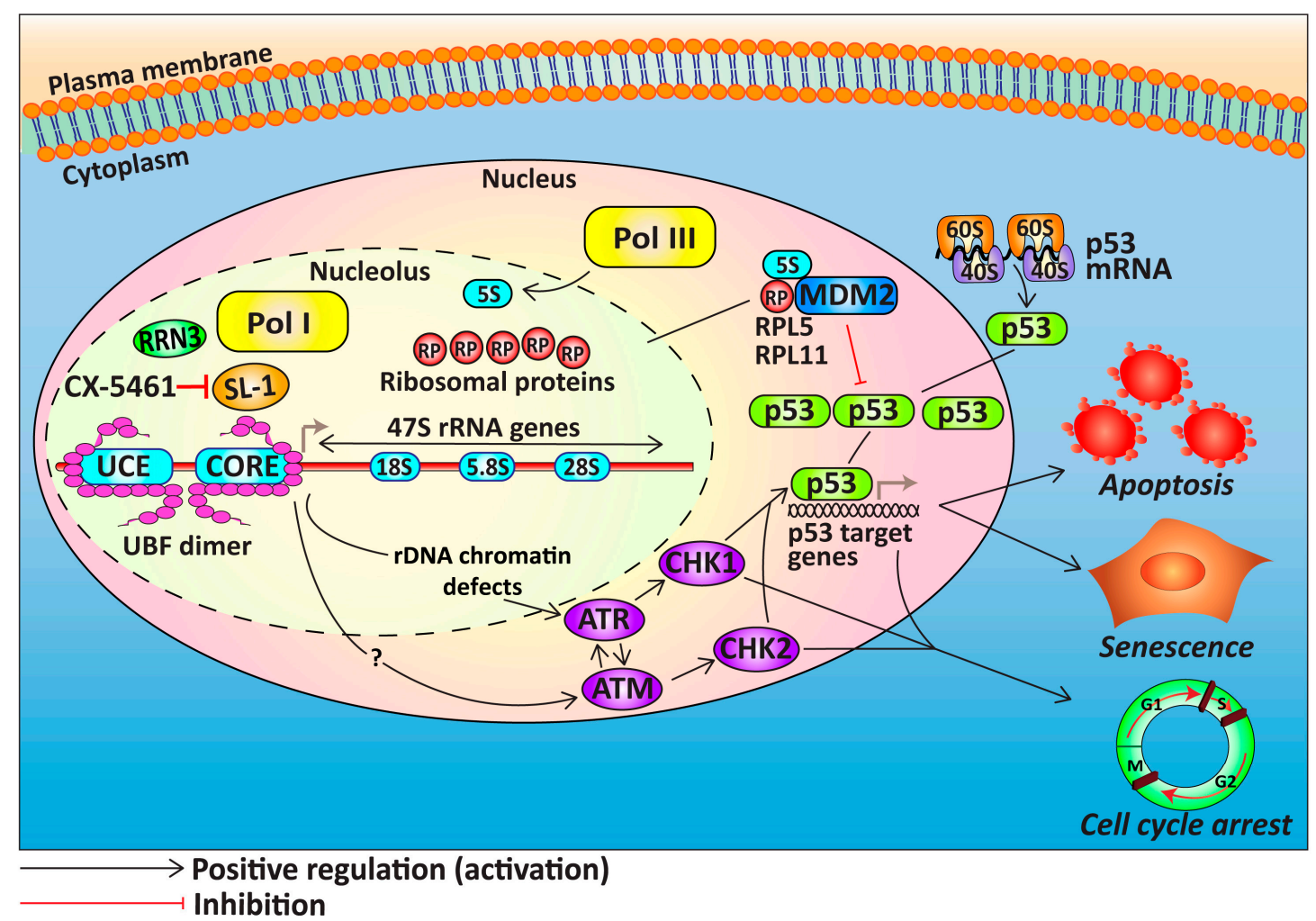

Figure 3. p53-dependent and -independent-mediated cellular response to CX-5461. The nucleolar stress response is initiated when ribosome biogenesis is perturbed by the Pol I transcription inhibitor, CX-5461. Central to this response is the stabilization and activation of the tumour suppressor protein p53, which triggers cell-cycle arrest, apoptosis, or senescence in a context-dependent manner. Upon alterations in ribosome biogenesis rate, free ribosomal proteins (RPs), in particular RPL5 and RPL11 in a complex with $5 \mathrm{~S}$ rRNA, are released from the nucleolus into the nucleus to sequester the E3 ubiquitin ligase MDM2 leading to p53 stabilization. Importantly for HGSOC, CX-5461 also induces chromatin defects at rRNA genes leading to non-canonical ATM/ATR signalling and p53-independent cell-cycle arrest. (RP: ribosomal proteins; Pol I: RNA Polymerase I; UCE: upstream control element; CORE: core promoter element; UBF: upstream binding factor; SL-1: selectivity factor 1; MDM2: Mouse double minute 2 homolog; ATM: ataxia telangiectasia mutated; ATR: ataxia telangiectasia and Rad3-related protein). Grey arrows denote ongoing transcription.

\section{The Potential of Targeting Ribosome Biogenesis in HGSOC}

Recent studies utilizing CX-5461 in combination therapy have demonstrated impressive results in targeting the intrinsic reliance of cancer cells on ribosome biogenesis. Indeed, targeting ribosome biogenesis and protein translation by combining CX-5461 with the mTORC1 inhibitor, everolimus, synergistically reduced tumour burden and provided remarkable improvement in survival rate of MYC-driven lymphoma-bearing mice [105]. The synergistic efficacy of this combination in vivo was due to more robust suppression of Pol I transcription compared to single-agent treatment as well as the induction of tumour cell death via independent pathways. CX-5461 induced nucleolar stress 
and p53 pathway activation, whereas everolimus induced expression of the pro-apoptotic protein BH-only protein BCL modifying factor (BMF) [105]. While the therapeutic efficacy of CX-5461 against MYC-driven B-cell lymphoma is linked to p53-mediated apoptosis, it is not restricted to p53 status in solid cancer cell lines [104]. Everolimus is currently being evaluated in phase I trial for OC [118,119] and the combination with CX-5461 may provide benefit for the treatment of this disease. Furthermore, a recent study has provided preclinical evidence demonstrating improved therapeutic efficacy in preclinical models of MYC-driven prostate cancer upon combined treatment of CX-5461 and an inhibitor of PIM kinase [106]. The oncogenic PIM kinase promotes c-MYC transcriptional activity and stability, as well as stimulating eIF4E-dependent mRNA translation. Strikingly, CX-5461 in combination therapy with the pan-PIM kinase inhibitor CX-6258, led to a reversion of Hi-MYC tumours back to high-grade intraepithelial neoplasia. In addition, this combination showed significant efficacy in an aggressive chemotherapy-refractory high MYC patient-derived xenograft (PDX) model of prostate cancer. These findings provide a further rationale for translating this combination therapy to HGSOC.

Moreover, as described in Section 4.2, CX-5461 induces a p53-independent ATM/ATR-mediated G2 cell-cycle checkpoint. The combination of CX-5461 with a drug targeting ATM/ATR signalling led to enhanced therapeutic benefit in treating p53-null MYC-driven lymphoma in vivo, which are normally refractory to either drug alone [107]. Inhibition of DNA damage response (DDR) signalling has become an attractive therapeutic strategy in cancer treatment with highly selective small molecule inhibitors of ATM and ATR signalling in preclinical and clinical development, respectively in OC thus providing a rationale for CX-5461 combination with DDR inhibitors in HGSOC treatment. Furthermore, CX-5461 was shown to sensitize primary fibroblasts to DNA-damaging agents [107], raising the possibility of enhancing the therapeutic efficacy against HGSOC by combining CX-5461 with standard chemotherapies (carboplatin/cisplatin) or emerging targeted therapies, such as PARP inhibitors. Potentially, the combination of APR-246 with CX-5461, which could restore p53 activity and allow increased p53 protein stabilization through CX-5461-mediated nucleolar stress response, may also prove effective against HGSOC.

\section{Conclusions}

While poly ADP-ribose polymerase (PARP) inhibitors have demonstrated promising therapeutic benefits in high-grade serous ovarian cancer (HGSOC) patients [120], there are concerns regarding the complexity of mechanisms underlying resistance to PARP inhibition. Thus, the possibility of enhancing the therapeutic efficacy against HGSOC by combining CX-5461 with PARP inhibitors or standard chemotherapies is an exciting novel approach for the treatment of this disease. In addition, combined targeting of ribosome biogenesis and protein translation may also be effective, such as combining CX-5461 with mammalian target of rapamycin (mTOR) inhibitors, by overcoming the redundancy of the retrovirus-associated DNA sequences (RAS) and phosphatidylinositol-3-kinase (PI3K) signalling networks and the complexity of resistance mechanisms to pathway inhibitors. The therapeutic inhibition of these drivers has the potential to overcome genetic heterogeneity and improve patient outcome.

While this review has focused on HGSOC, there is also a strong rationale for potential trials in the other histological subtypes. Rare OC subtypes have a very different molecular profile. Given frequent and occasional co-existing alterations in the RAS and PI3K pathways in low-grade serous ovarian cancer (LGSOC), targeting ribosome biogenesis may also be appropriate in this subgroup. Furthermore, LGSOC and endometrioid ovarian tumours frequently express hormone receptors; thus, combining endocrine treatment with CX-5461 in these subtypes is worthy of investigation.

To date, CX-5461 is well tolerated with low-grade manageable adverse events in 13 patients with advanced haematological malignancies while the trial continues with dose escalation [121]. Certainly, preclinical studies utilizing CX-5461 indicate that targeting ribosome biogenesis will be most efficacious in tumours with dysregulated growth control downstream of the v-myc avian myelocytomatosis viral oncogene homolog (MYC) and PI3K nodes $[96,105]$ and potentially deregulated 
DNA damage response (DDR) [107]. Understanding mechanisms of cellular response to targeting ribosome biogenesis in various tumour types, as well as identifying predictive biomarkers of response, will be crucial for the success of this novel class of targeted therapy and for the development of rational combinatorial strategies.

Acknowledgments: This work was supported by the National Health and Medical Research Council (NHMRC) of Australia, project grants (\#1043884, 251608, 566702, 166908, 251688, 509087, 400116, 400120, 566876) and a NHMRC Program Grant (\#1053792). Cancer Council Victoria research grant (\#1065118). Ross D. Hannan and Richard B. Pearson were funded by NHMRC Fellowships.

Author Contributions: All authors contributed to the conception and writing of the manuscript.

Conflicts of Interest: Ross D. Hannan and Richard B. Pearson are Scientific Advisors to Pimera Inc. No potential conflicts of interest were disclosed by the other authors.

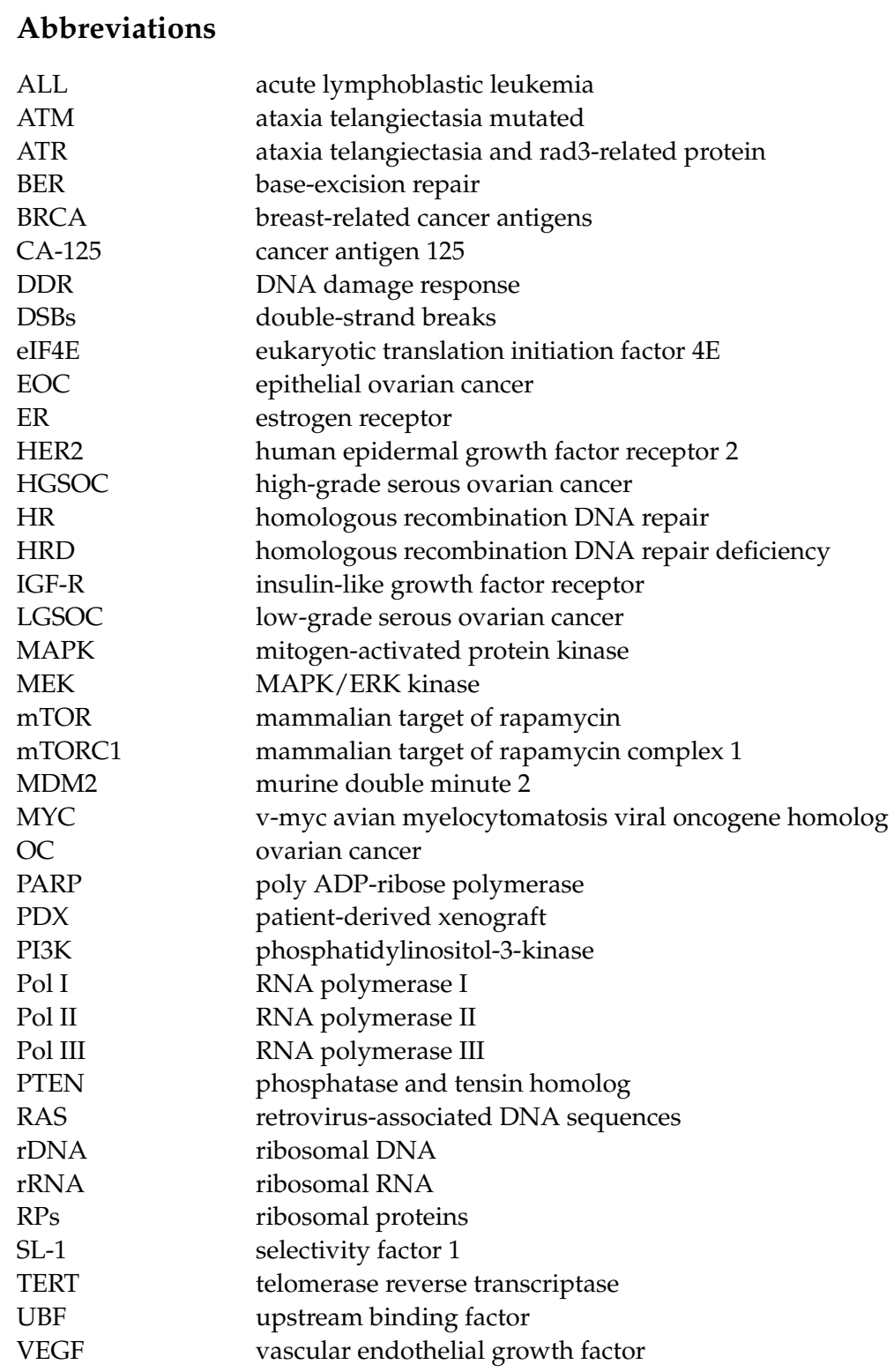

\section{References}

1. Ferlay, J.; Soerjomataram, I.; Dikshit, R.; Eser, S.; Mathers, C.; Rebelo, M.; Parkin, D.M.; Forman, D.; Bray, F. Cancer incidence and mortality worldwide: Sources, methods and major patterns in globocan 2012. Int. J. Cancer 2015, 136, E359-E386. [CrossRef] [PubMed] 
2. Lokadasan, R.; James, F.V.; Narayanan, G.; Prabhakaran, P.K. Targeted agents in epithelial ovarian cancer: Review on emerging therapies and future developments. Ecancermedicalscience 2016, 10, 626. [CrossRef] [PubMed]

3. National Cancer Institute. Surveillance, Epidemiology and End Results Program. Available online: https: //seer.cancer.gov (accessed on 1 December 2016).

4. Erickson, B.K.; Conner, M.G.; Landen, C.N., Jr. The role of the fallopian tube in the origin of ovarian cancer. Am. J. Obstet. Gynecol. 2013, 209, 409-414. [CrossRef] [PubMed]

5. Bowtell, D.D. The genesis and evolution of high-grade serous ovarian cancer. Nat. Rev. Cancer 2010, 10, 803-808. [CrossRef] [PubMed]

6. Koulouris, C.R.; Penson, R.T. Ovarian stromal and germ cell tumors. Semin. Oncol. 2009, 36, 126-136. [CrossRef] [PubMed]

7. Landen, C.N., Jr.; Birrer, M.J.; Sood, A.K. Early events in the pathogenesis of epithelial ovarian cancer. J. Clin. Oncol. 2008, 26, 995-1005. [CrossRef] [PubMed]

8. The Cancer Genome Atlas Research Network. Integrated genomic analyses of ovarian carcinoma. Nature 2011, 474, 609-615.

9. Vang, R.; Shih Ie, M.; Kurman, R.J. Ovarian low-grade and high-grade serous carcinoma: Pathogenesis, clinicopathologic and molecular biologic features, and diagnostic problems. Adv. Anat. Pathol. 2009, 16, 267-282. [CrossRef] [PubMed]

10. Kurman, R.J.; Shih Ie, M. Molecular pathogenesis and extraovarian origin of epithelial ovarian cancer-Shifting the paradigm. Hum. Pathol. 2011, 42, 918-931. [CrossRef] [PubMed]

11. Bowtell, D.D.; Bohm, S.; Ahmed, A.A.; Aspuria, P.J.; Bast, R.C., Jr.; Beral, V.; Berek, J.S.; Birrer, M.J.; Blagden, S.; Bookman, M.A.; et al. Rethinking ovarian cancer ii: Reducing mortality from high-grade serous ovarian cancer. Nat. Rev. Cancer 2015, 15, 668-679. [CrossRef] [PubMed]

12. Seidman, J.D.; Horkayne-Szakaly, I.; Haiba, M.; Boice, C.R.; Kurman, R.J.; Ronnett, B.M. The histologic type and stage distribution of ovarian carcinomas of surface epithelial origin. Int. J. Gynecol. Pathol. 2004, 23, 41-44. [CrossRef] [PubMed]

13. Tothill, R.W.; Tinker, A.V.; George, J.; Brown, R.; Fox, S.B.; Lade, S.; Johnson, D.S.; Trivett, M.K.; Etemadmoghadam, D.; Locandro, B.; et al. Novel molecular subtypes of serous and endometrioid ovarian cancer linked to clinical outcome. Clin. Cancer Res. 2008, 14, 5198-5208. [CrossRef] [PubMed]

14. Tan, T.Z.; Miow, Q.H.; Huang, R.Y.; Wong, M.K.; Ye, J.; Lau, J.A.; Wu, M.C.; Bin Abdul Hadi, L.H.; Soong, R.; Choolani, M.; et al. Functional genomics identifies five distinct molecular subtypes with clinical relevance and pathways for growth control in epithelial ovarian cancer. EMBO Mol. Med. 2013, 5, 1051-1066. [CrossRef] [PubMed]

15. Ahmed, A.A.; Etemadmoghadam, D.; Temple, J.; Lynch, A.G.; Riad, M.; Sharma, R.; Stewart, C.; Fereday, S.; Caldas, C.; Defazio, A.; et al. Driver mutations in tp53 are ubiquitous in high grade serous carcinoma of the ovary. J. Pathol. 2010, 221, 49-56. [CrossRef] [PubMed]

16. Pal, T.; Permuth-Wey, J.; Betts, J.A.; Krischer, J.P.; Fiorica, J.; Arango, H.; LaPolla, J.; Hoffman, M.; Martino, M.A.; Wakeley, K.; et al. BRCA1 and BRCA2 mutations account for a large proportion of ovarian carcinoma cases. Cancer 2005, 104, 2807-2816. [CrossRef] [PubMed]

17. Konstantinopoulos, P.A.; Ceccaldi, R.; Shapiro, G.I.; D'Andrea, A.D. Homologous recombination deficiency: Exploiting the fundamental vulnerability of ovarian cancer. Cancer Discov. 2015, 5, 1137-1154. [CrossRef] [PubMed]

18. Alsop, K.; Fereday, S.; Meldrum, C.; deFazio, A.; Emmanuel, C.; George, J.; Dobrovic, A.; Birrer, M.J.; Webb, P.M.; Stewart, C.; et al. BRCA mutation frequency and patterns of treatment response in brca mutation-positive women with ovarian cancer: A report from the australian ovarian cancer study group. J. Clin. Oncol. 2012, 30, 2654-2663. [CrossRef] [PubMed]

19. Bast, R.C., Jr.; Klug, T.L.; St John, E.; Jenison, E.; Niloff, J.M.; Lazarus, H.; Berkowitz, R.S.; Leavitt, T.; Griffiths, C.T.; Parker, L.; et al. A radioimmunoassay using a monoclonal antibody to monitor the course of epithelial ovarian cancer. N. Engl. J. Med. 1983, 309, 883-887. [CrossRef] [PubMed]

20. Menon, U.; Gentry-Maharaj, A.; Hallett, R.; Ryan, A.; Burnell, M.; Sharma, A.; Lewis, S.; Davies, S.; Philpott, S.; Lopes, A.; et al. Sensitivity and specificity of multimodal and ultrasound screening for ovarian cancer, and stage distribution of detected cancers: Results of the prevalence screen of the uk collaborative trial of ovarian cancer screening (UKCTOCS). Lancet Oncol. 2009, 10, 327-340. [CrossRef] 
21. Kulasingam, V.; Pavlou, M.P.; Diamandis, E.P. Integrating high-throughput technologies in the quest for effective biomarkers for ovarian cancer. Nat. Rev. Cancer 2010, 10, 371-378. [CrossRef] [PubMed]

22. Bast, R.C., Jr.; Hennessy, B.; Mills, G.B. The biology of ovarian cancer: New opportunities for translation. Nat. Rev. Cancer 2009, 9, 415-428. [CrossRef] [PubMed]

23. Siddik, Z.H. Cisplatin: Mode of cytotoxic action and molecular basis of resistance. Oncogene 2003, 22, 7265-7279. [CrossRef] [PubMed]

24. Cepeda, V.; Fuertes, M.A.; Castilla, J.; Alonso, C.; Quevedo, C.; Perez, J.M. Biochemical mechanisms of cisplatin cytotoxicity. Anticancer Agents Med. Chem. 2007, 7, 3-18. [CrossRef] [PubMed]

25. Jordan, M.A.; Wilson, L. Microtubules as a target for anticancer drugs. Nat. Rev. Cancer 2004, 4, $253-265$. [CrossRef] [PubMed]

26. Heintz, A.P.; Odicino, F.; Maisonneuve, P.; Quinn, M.A.; Benedet, J.L.; Creasman, W.T.; Ngan, H.Y.; Pecorelli, S.; Beller, U. Carcinoma of the ovary. Figo 26th annual report on the results of treatment in gynecological cancer. Int. J. Gynaecol. Obstet. 2006, 95 (Suppl. S1), S161-S192. [CrossRef]

27. Chetrit, A.; Hirsh-Yechezkel, G.; Ben-David, Y.; Lubin, F.; Friedman, E.; Sadetzki, S. Effect of brca1/2 mutations on long-term survival of patients with invasive ovarian cancer: The national israeli study of ovarian cancer. J. Clin. Oncol. 2008, 26, 20-25. [CrossRef] [PubMed]

28. Bolton, K.L.; Chenevix-Trench, G.; Goh, C.; Sadetzki, S.; Ramus, S.J.; Karlan, B.Y.; Lambrechts, D.; Despierre, E.; Barrowdale, D.; McGuffog, L.; et al. Association between BRCA1 and BRCA2 mutations and survival in women with invasive epithelial ovarian cancer. JAMA 2012, 307, 382-390. [CrossRef] [PubMed]

29. Yap, T.A.; Carden, C.P.; Kaye, S.B. Beyond chemotherapy: Targeted therapies in ovarian cancer. Nat. Rev. Cancer 2009, 9, 167-181. [CrossRef] [PubMed]

30. Agarwal, R.; Kaye, S.B. Ovarian cancer: Strategies for overcoming resistance to chemotherapy. Nat. Rev. Cancer 2003, 3, 502-516. [CrossRef] [PubMed]

31. Swisher, E.M.; Sakai, W.; Karlan, B.Y.; Wurz, K.; Urban, N.; Taniguchi, T. Secondary BRCA1 mutations in BRCA1-mutated ovarian carcinomas with platinum resistance. Cancer Res. 2008, 68, 2581-2586. [CrossRef] [PubMed]

32. Sakai, W.; Swisher, E.M.; Karlan, B.Y.; Agarwal, M.K.; Higgins, J.; Friedman, C.; Villegas, E.; Jacquemont, C.; Farrugia, D.J.; Couch, F.J.; et al. Secondary mutations as a mechanism of cisplatin resistance in BRCA2-mutated cancers. Nature 2008, 451, 1116-1120. [CrossRef] [PubMed]

33. Cooke, S.L.; Brenton, J.D. Evolution of platinum resistance in high-grade serous ovarian cancer. Lancet Oncol. 2011, 12, 1169-1174. [CrossRef]

34. Patch, A.M.; Christie, E.L.; Etemadmoghadam, D.; Garsed, D.W.; George, J.; Fereday, S.; Nones, K.; Cowin, P.; Alsop, K.; Bailey, P.J.; et al. Whole-genome characterization of chemoresistant ovarian cancer. Nature 2015, 521, 489-494. [CrossRef] [PubMed]

35. Markman, M.; Bookman, M.A. Second-line treatment of ovarian cancer. Oncologist 2000, 5, 26-35. [CrossRef] [PubMed]

36. Luvero, D.; Milani, A.; Ledermann, J.A. Treatment options in recurrent ovarian cancer: Latest evidence and clinical potential. Ther. Adv. Med. Oncol. 2014, 6, 229-239. [CrossRef] [PubMed]

37. Pujade-Lauraine, E.; Hilpert, F.; Weber, B.; Reuss, A.; Poveda, A.; Kristensen, G.; Sorio, R.; Vergote, I.; Witteveen, P.; Bamias, A.; et al. Bevacizumab combined with chemotherapy for platinum-resistant recurrent ovarian cancer: The aurelia open-label randomized phase iii trial. J. Clin. Oncol. 2014, 32, 1302-1308. [CrossRef] [PubMed]

38. Perren, T.J.; Swart, A.M.; Pfisterer, J.; Ledermann, J.A.; Pujade-Lauraine, E.; Kristensen, G.; Carey, M.S.; Beale, P.; Cervantes, A.; Kurzeder, C.; et al. A phase 3 trial of bevacizumab in ovarian cancer. N. Engl. J. Med. 2011, 365, 2484-2496. [CrossRef] [PubMed]

39. Oza, A.M.; Cook, A.D.; Pfisterer, J.; Embleton, A.; Ledermann, J.A.; Pujade-Lauraine, E.; Kristensen, G.; Carey, M.S.; Beale, P.; Cervantes, A.; et al. Standard chemotherapy with or without bevacizumab for women with newly diagnosed ovarian cancer (ICON7): Overall survival results of a phase 3 randomised trial. Lancet Oncol. 2015, 16, 928-936. [CrossRef]

40. Ledermann, J.; Harter, P.; Gourley, C.; Friedlander, M.; Vergote, I.; Rustin, G.; Scott, C.L.; Meier, W.; Shapira-Frommer, R.; Safra, T.; et al. Olaparib maintenance therapy in patients with platinum-sensitive relapsed serous ovarian cancer: A preplanned retrospective analysis of outcomes by BRCA status in a randomised phase 2 trial. Lancet Oncol. 2014, 15, 852-861. [CrossRef] 
41. Farmer, H.; McCabe, N.; Lord, C.J.; Tutt, A.N.; Johnson, D.A.; Richardson, T.B.; Santarosa, M.; Dillon, K.J.; Hickson, I.; Knights, C.; et al. Targeting the DNA repair defect in brca mutant cells as a therapeutic strategy. Nature 2005, 434, 917-921. [CrossRef] [PubMed]

42. Ledermann, J.; Harter, P.; Gourley, C.; Friedlander, M.; Vergote, I.; Rustin, G.; Scott, C.; Meier, W.; Shapira-Frommer, R.; Safra, T.; et al. Olaparib maintenance therapy in platinum-sensitive relapsed ovarian cancer. N. Engl. J. Med. 2012, 366, 1382-1392. [CrossRef] [PubMed]

43. Ledermann, J.A.; Drew, Y.; Kristeleit, R.S. Homologous recombination deficiency and ovarian cancer. Eur. J. Cancer 2016, 60, 49-58. [CrossRef] [PubMed]

44. Scott, C.L.; Swisher, E.M.; Kaufmann, S.H. Poly (ADP-ribose) polymerase inhibitors: Recent advances and future development. J. Clin. Oncol. 2015, 33, 1397-1406. [CrossRef] [PubMed]

45. Mirza, M.R.; Monk, B.J.; Herrstedt, J.; Oza, A.M.; Mahner, S.; Redondo, A.; Fabbro, M.; Ledermann, J.A.; Lorusso, D.; Vergote, I.; et al. Niraparib maintenance therapy in platinum-sensitive, recurrent ovarian cancer. N. Engl. J. Med. 2016, 375, 2154-2164. [CrossRef] [PubMed]

46. Lambert, J.M.; Moshfegh, A.; Hainaut, P.; Wiman, K.G.; Bykov, V.J. Mutant p53 reactivation by prima-1met induces multiple signaling pathways converging on apoptosis. Oncogene 2010, 29, 1329-1338. [CrossRef] [PubMed]

47. Lambert, J.M.; Gorzov, P.; Veprintsev, D.B.; Soderqvist, M.; Segerback, D.; Bergman, J.; Fersht, A.R.; Hainaut, P.; Wiman, K.G.; Bykov, V.J. Prima-1 reactivates mutant p53 by covalent binding to the core domain. Cancer Cell 2009, 15, 376-388. [CrossRef] [PubMed]

48. Fransson, A.; Glaessgen, D.; Alfredsson, J.; Wiman, K.G.; Bajalica-Lagercrantz, S.; Mohell, N. Strong synergy with APR-246 and DNA-damaging drugs in primary cancer cells from patients with tp53 mutant high-grade serous ovarian cancer. J. Ovarian Res. 2016, 9, 27. [CrossRef] [PubMed]

49. Cheaib, B.; Auguste, A.; Leary, A. The PI3K/Akt/mTOR pathway in ovarian cancer: Therapeutic opportunities and challenges. Chin. J. Cancer 2015, 34, 4-16. [CrossRef] [PubMed]

50. Sheppard, K.E.; Cullinane, C.; Hannan, K.M.; Wall, M.; Chan, J.; Barber, F.; Foo, J.; Cameron, D.; Neilsen, A.; $\mathrm{Ng}$, P.; et al. Synergistic inhibition of ovarian cancer cell growth by combining selective PI3K/mTOR and RAS/ERK pathway inhibitors. Eur. J. Cancer 2013, 49, 3936-3944. [CrossRef] [PubMed]

51. Kinross, K.M.; Brown, D.V.; Kleinschmidt, M.; Jackson, S.; Christensen, J.; Cullinane, C.; Hicks, R.J.; Johnstone, R.W.; McArthur, G.A. In vivo activity of combined PI3K/mTOR and mek inhibition in a kras(G12D);pten deletion mouse model of ovarian cancer. Mol. Cancer Ther. 2011, 10, 1440-1449. [CrossRef] [PubMed]

52. Fruman, D.A.; Rommel, C. PI3K and cancer: Lessons, challenges and opportunities. Nat. Rev. Drug Discov. 2014, 13, 140-156. [CrossRef] [PubMed]

53. Altomare, D.A.; Wang, H.Q.; Skele, K.L.; De Rienzo, A.; Klein-Szanto, A.J.; Godwin, A.K.; Testa, J.R. Akt and mtor phosphorylation is frequently detected in ovarian cancer and can be targeted to disrupt ovarian tumor cell growth. Oncogene 2004, 23, 5853-5857. [CrossRef] [PubMed]

54. Kuo, K.T.; Mao, T.L.; Jones, S.; Veras, E.; Ayhan, A.; Wang, T.L.; Glas, R.; Slamon, D.; Velculescu, V.E.; Kuman, R.J.; et al. Frequent activating mutations of pik3ca in ovarian clear cell carcinoma. Am. J. Pathol. 2009, 174, 1597-1601. [CrossRef] [PubMed]

55. Hafsi, S.; Pezzino, F.M.; Candido, S.; Ligresti, G.; Spandidos, D.A.; Soua, Z.; McCubrey, J.A.; Travali, S.; Libra, M. Gene alterations in the PI3K/pten/akt pathway as a mechanism of drug-resistance (review). Int. J. Oncol. 2012, 40, 639-644. [PubMed]

56. King, E.R.; Zu, Z.; Tsang, Y.T.; Deavers, M.T.; Malpica, A.; Mok, S.C.; Gershenson, D.M.; Wong, K.K. The insulin-like growth factor 1 pathway is a potential therapeutic target for low-grade serous ovarian carcinoma. Gynecol. Oncol. 2011, 123, 13-18. [CrossRef] [PubMed]

57. Mabuchi, S.; Kuroda, H.; Takahashi, R.; Sasano, T. The PI3K/Akt/mTOR pathway as a therapeutic target in ovarian cancer. Gynecol. Oncol. 2015, 137, 173-179. [CrossRef] [PubMed]

58. Carracedo, A.; Pandolfi, P.P. The pten-PI3K pathway: Of feedbacks and cross-talks. Oncogene 2008, 27, 5527-5541. [CrossRef] [PubMed]

59. Koul, A.; Willen, R.; Bendahl, P.O.; Nilbert, M.; Borg, A. Distinct sets of gene alterations in endometrial carcinoma implicate alternate modes of tumorigenesis. Cancer 2002, 94, 2369-2379. [CrossRef] [PubMed] 
60. Ryland, G.L.; Hunter, S.M.; Doyle, M.A.; Caramia, F.; Li, J.; Rowley, S.M.; Christie, M.; Allan, P.E.; Stephens, A.N.; Bowtell, D.D.; et al. Mutational landscape of mucinous ovarian carcinoma and its neoplastic precursors. Genome Med. 2015, 7, 87. [CrossRef] [PubMed]

61. Farley, J.; Brady, W.E.; Vathipadiekal, V.; Lankes, H.A.; Coleman, R.; Morgan, M.A.; Mannel, R.; Yamada, S.D.; Mutch, D.; Rodgers, W.H.; et al. Selumetinib in women with recurrent low-grade serous carcinoma of the ovary or peritoneum: An open-label, single-arm, phase 2 study. Lancet Oncol. 2013, 14, 134-140. [CrossRef]

62. Coward, J.I.; Middleton, K.; Murphy, F. New perspectives on targeted therapy in ovarian cancer. Int. J. Womens Health 2015, 7, 189-203. [CrossRef] [PubMed]

63. Coleman, R.L.; Sill, M.W.; Thaker, P.H.; Bender, D.P.; Street, D.; McGuire, W.P.; Johnston, C.M.; Rotmensch, J. A phase ii evaluation of selumetinib (AZD6244, ARRY-142886), a selective mek-1/2 inhibitor in the treatment of recurrent or persistent endometrial cancer: An nrg oncology/gynecologic oncology group study. Gynecol. Oncol. 2015, 138, 30-35. [CrossRef] [PubMed]

64. Gershenson, D.M. The life and times of low-grade serous carcinoma of the ovary. Am. Soc. Clin Oncol. Educ. Book 2013. [CrossRef] [PubMed]

65. Wierstra, I.; Alves, J. The c-MYC promoter: Still mystery and challenge. Adv. Cancer Res. 2008, 99, $113-333$. [PubMed]

66. Pyndiah, S.; Tanida, S.; Ahmed, K.M.; Cassimere, E.K.; Choe, C.; Sakamuro, D. c-MYC suppresses bin1 to release poly(ADP-ribose) polymerase 1: A mechanism by which cancer cells acquire cisplatin resistance. Sci. Signal. 2011, 4, ra19. [CrossRef] [PubMed]

67. Van Riggelen, J.; Yetil, A.; Felsher, D.W. Myc as a regulator of ribosome biogenesis and protein synthesis. Nat. Rev. Cancer 2010, 10, 301-309. [CrossRef] [PubMed]

68. Poortinga, G.; Wall, M.; Sanij, E.; Siwicki, K.; Ellul, J.; Brown, D.; Holloway, T.P.; Hannan, R.D.; McArthur, G.A. c-MYC coordinately regulates ribosomal gene chromatin remodeling and Pol I availability during granulocyte differentiation. Nucleic Acids Res. 2011, 39, 3267-3281. [CrossRef] [PubMed]

69. Poortinga, G.; Quinn, L.M.; Hannan, R.D. Targeting rna polymerase i to treat myc-driven cancer. Oncogene 2014, 34, 403-412. [CrossRef] [PubMed]

70. Grandori, C.; Gomez-Roman, N.; Felton-Edkins, Z.A.; Ngouenet, C.; Galloway, D.A.; Eisenman, R.N.; White, R.J. c-MYC binds to human ribosomal DNA and stimulates transcription of rna genes by rna polymerase i. Nat. Cell Biol. 2005, 7, 311-318. [CrossRef] [PubMed]

71. Arabi, A.; Wu, S.; Ridderstrale, K.; Bierhoff, H.; Shiue, C.; Fatyol, K.; Fahlen, S.; Hydbring, P.; Soderberg, O.; Grummt, I.; et al. c-MYC associates with ribosomal DNA and activates rna polymerase I transcription. Nat. Cell Biol. 2005, 7, 303-310. [CrossRef] [PubMed]

72. Shiue, C.N.; Berkson, R.G.; Wright, A.P. c-MYC induces changes in higher order rdna structure on stimulation of quiescent cells. Oncogene 2009, 28, 1833-1842. [CrossRef] [PubMed]

73. Poortinga, G.; Hannan, K.M.; Snelling, H.; Walkley, C.R.; Jenkins, A.; Sharkey, K.; Wall, M.; Brandenburger, Y.; Palatsides, M.; Pearson, R.B.; et al. Mad1 and c-MYC regulate UBF and rDNA transcription during granulocyte differentiation. EMBO J. 2004, 23, 3325-3335. [CrossRef] [PubMed]

74. Schmidt, E.V. The role of c-MYC in regulation of translation initiation. Oncogene 2004, 23, 3217-3221. [CrossRef] [PubMed]

75. Ruggero, D. The role of myc-induced protein synthesis in cancer. Cancer Res. 2009, 69, 8839-8843. [CrossRef] [PubMed]

76. Hannan, K.M.; Sanij, E.; Hein, N.; Hannan, R.D.; Pearson, R.B. Signaling to the ribosome in cancer-It is more than just mtorc1. IUBMB Life 2011, 63, 79-85. [CrossRef] [PubMed]

77. Gentilella, A.; Kozma, S.C.; Thomas, G. A liaison between mtor signaling, ribosome biogenesis and cancer. Biochim. Biophys. Acta 2015, 1849, 812-820. [CrossRef] [PubMed]

78. Altomare, D.A.; Testa, J.R. Perturbations of the akt signaling pathway in human cancer. Oncogene 2005, 24, 7455-7464. [CrossRef] [PubMed]

79. Memmott, R.M.; Dennis, P.A. Akt-dependent and -independent mechanisms of mtor regulation in cancer. Cell Signal. 2009, 21, 656-664. [CrossRef] [PubMed]

80. Chan, J.C.; Hannan, K.M.; Riddell, K.; Ng, P.Y.; Peck, A.; Lee, R.S.; Hung, S.; Astle, M.V.; Bywater, M.; Wall, M.; et al. Akt promotes rrna synthesis and cooperates with c-MYC to stimulate ribosome biogenesis in cancer. Sci. Signal 2011, 4, ra56. [CrossRef] [PubMed] 
81. Devlin, J.R.; Hannan, K.M.; Ng, P.Y.; Bywater, M.J.; Shortt, J.; Cullinane, C.; McArthur, G.A.; Johnstone, R.W.; Hannan, R.D.; Pearson, R.B. Akt signalling is required for ribosomal rna synthesis and progression of EMU-MYC B-cell lymphoma in vivo. FEBS J. 2013, 280, 5307-5316. [CrossRef] [PubMed]

82. Stefanovsky, V.Y.; Pelletier, G.; Hannan, R.; Gagnon-Kugler, T.; Rothblum, L.I.; Moss, T. An immediate response of ribosomal transcription to growth factor stimulation in mammals is mediated by erk phosphorylation of ubf. Mol. Cell 2001, 8, 1063-1073. [CrossRef]

83. Zhao, J.; Yuan, X.; Frödin, M.; Grummt, I. Erk-dependent phosphorylation of the transcription initiation factor tif-ia is required for rna polymerase i transcription and cell growth. Mol. Cell 2003, 11, 405-413. [CrossRef]

84. Leary, D.J.; Huang, S. Regulation of ribosome biogenesis within the nucleolus. FEBS Lett. 2001, 509, 145-150. [CrossRef]

85. Tschochner, H.; Hurt, E. Pre-ribosomes on the road from the nucleolus to the cytoplasm. Trends Cell Biol. 2003, 13, 255-263. [CrossRef]

86. Schmidt, E.V. The role of c-MYC in cellular growth control. Oncogene 1999, 18, 2988-2996. [CrossRef] [PubMed]

87. Moss, T.; Langlois, F.; Gagnon-Kugler, T.; Stefanovsky, V. A housekeeper with power of attorney: The rrna genes in ribosome biogenesis. Cell. Mol. Life Sci. 2007, 64, 29-49. [CrossRef] [PubMed]

88. Moir, R.D.; Willis, I.M. Regulation of pol iii transcription by nutrient and stress signaling pathways. Biochim. Biophys. Acta 2013, 1829, 361-375. [CrossRef] [PubMed]

89. Hannan, K.M.; Sanij, E.; Rothblum, L.I.; Hannan, R.D.; Pearson, R.B. Dysregulation of rna polymerase I transcription during disease. Biochim. Biophys. Acta 2013, 1829, 342-360. [CrossRef] [PubMed]

90. Diesch, J.; Hannan, R.D.; Sanij, E. Perturbations at the ribosomal genes loci are at the centre of cellular dysfunction and human disease. Cell Biosci. 2014, 4, 43. [CrossRef] [PubMed]

91. Ruggero, D. Revisiting the nucleolus: From marker to dynamic integrator of cancer signaling. Sci. Signal 2012, 5, pe38. [CrossRef] [PubMed]

92. Ruggero, D.; Pandolfi, P.P. Does the ribosome translate cancer? Nat. Rev. Cancer 2003, 3, 179-192. [CrossRef] [PubMed]

93. Derenzini, M.; Trere, D.; Pession, A.; Govoni, M.; Sirri, V.; Chieco, P. Nucleolar size indicates the rapidity of cell proliferation in cancer tissues. J. Pathol. 2000, 191, 181-186. [CrossRef]

94. Derenzini, M.; Trere, D.; Pession, A.; Montanaro, L.; Sirri, V.; Ochs, R.L. Nucleolar function and size in cancer cells. Am. J. Pathol. 1998, 152, 1291-1297. [PubMed]

95. Bywater, M.J.; Pearson, R.B.; McArthur, G.A.; Hannan, R.D. Dysregulation of the basal rna polymerase transcription apparatus in cancer. Nat. Rev. Cancer 2013, 13, 299-314. [CrossRef] [PubMed]

96. Bywater, M.J.; Poortinga, G.; Sanij, E.; Hein, N.; Peck, A.; Cullinane, C.; Wall, M.; Cluse, L.; Drygin, D.; Anderes, K.; et al. Inhibition of RNA polymerase I as a therapeutic strategy to promote cancer-specific activation of p53. Cancer Cell 2012, 22, 51-65. [CrossRef] [PubMed]

97. Burger, K.; Eick, D. Functional ribosome biogenesis is a prerequisite for p53 destabilization: Impact of chemotherapy on nucleolar functions and rna metabolism. Biol. Chem. 2013, 394, 1133-1143. [CrossRef] [PubMed]

98. Vlatkovic, N.; Boyd, M.T.; Rubbi, C.P. Nucleolar control of p53: A cellular achilles' heel and a target for cancer therapy. Cell. Mol. Life Sci. 2014, 71, 771-791. [CrossRef] [PubMed]

99. Burger, K.; Muhl, B.; Harasim, T.; Rohrmoser, M.; Malamoussi, A.; Orban, M.; Kellner, M.; Gruber-Eber, A.; Kremmer, E.; Holzel, M.; et al. Chemotherapeutic drugs inhibit ribosome biogenesis at various levels. J. Biol. Chem. 2010, 285, 12416-12425. [CrossRef] [PubMed]

100. Hein, N.; Hannan, K.M.; George, A.J.; Sanij, E.; Hannan, R.D. The nucleolus: An emerging target for cancer therapy. Trends Mol. Med. 2013, 19, 643-654. [CrossRef] [PubMed]

101. Quin, J.E.; Devlin, J.R.; Cameron, D.; Hannan, K.M.; Pearson, R.B.; Hannan, R.D. Targeting the nucleolus for cancer intervention. Biochim. Biophys. Acta 2014, 1842, 802-816. [CrossRef] [PubMed]

102. Drygin, D.; Rice, W.G.; Grummt, I. The rna polymerase i transcription machinery: An emerging target for the treatment of cancer. Annu. Rev. Pharmacol. Toxicol. 2010, 50, 131-156. [CrossRef] [PubMed]

103. Peltonen, K.; Colis, L.; Liu, H.; Trivedi, R.; Moubarek, M.S.; Moore, H.M.; Bai, B.; Rudek, M.A.; Bieberich, C.J.; Laiho, M. A targeting modality for destruction of rna polymerase $i$ that possesses anticancer activity. Cancer Cell 2014, 25, 77-90. [CrossRef] [PubMed] 
104. Drygin, D.; Lin, A.; Bliesath, J.; Ho, C.B.; O’Brien, S.E.; Proffitt, C.; Omori, M.; Haddach, M.; Schwaebe, M.K.; Siddiqui-Jain, A.; et al. Targeting rna polymerase I with an oral small molecule cx-5461 inhibits ribosomal rna synthesis and solid tumor growth. Cancer Res. 2011, 71, 1418-1430. [CrossRef] [PubMed]

105. Devlin, J.R.; Hannan, K.M.; Hein, N.; Cullinane, C.; Kusnadi, E.; Ng, P.Y.; George, A.J.; Shortt, J.; Bywater, M.J.; Poortinga, G.; et al. Combination therapy targeting ribosome biogenesis and mrna translation synergistically extends survival in myc-driven lymphoma. Cancer Discov. 2016, 6, 59-70. [CrossRef] [PubMed]

106. Rebello, R.J.; Kusnadi, E.; Cameron, D.P.; Pearson, H.B.; Lesmana, A.; Devlin, J.R.; Drygin, D.; Clark, A.K.; Porter, L.; Pedersen, J.; et al. The dual inhibition of rna Pol I transcription and pim kinase as a new therapeutic approach to treat advanced prostate cancer. Clin. Cancer Res. 2016. [CrossRef] [PubMed]

107. Quin, J.; Chan, K.T.; Devlin, J.R.; Cameron, D.P.; Diesch, J.; Cullinane, C.; Ahern, J.; Khot, A.; Hein, N.; George, A.J.; et al. Inhibition of rna polymerase i transcription initiation by CX-5461 activates non-canonical atm/atr signaling. Oncotarget 2016, 7, 49800-49818. [CrossRef] [PubMed]

108. Woods, S.J.; Hannan, K.M.; Pearson, R.B.; Hannan, R.D. The nucleolus as a fundamental regulator of the p53 response and a new target for cancer therapy. Biochim. Biophys. Acta 2015, 1849, 821-829. [CrossRef] [PubMed]

109. Boulon, S.; Westman, B.J.; Hutten, S.; Boisvert, F.M.; Lamond, A.I. The nucleolus under stress. Mol. Cell 2010, 40, 216-227. [CrossRef] [PubMed]

110. Zhang, Y.; Lu, H. Signaling to p53: Ribosomal proteins find their way. Cancer Cell 2009, 16, 369-377. [CrossRef] [PubMed]

111. Horn, H.F.; Vousden, K.H. Cooperation between the ribosomal proteins 15 and 111 in the p53 pathway. Oncogene 2008, 27, 5774-5784. [CrossRef] [PubMed]

112. Fumagalli, S.; Ivanenkov, V.V.; Teng, T.; Thomas, G. Suprainduction of p53 by disruption of $40 \mathrm{~S}$ and $60 \mathrm{~S}$ ribosome biogenesis leads to the activation of a novel g2/m checkpoint. Genes Dev. 2012, 26, 1028-1040. [CrossRef] [PubMed]

113. Vogelstein, B.; Lane, D.; Levine, A.J. Surfing the p53 network. Nature 2000, 408, 307-310. [CrossRef] [PubMed]

114. Horn, H.F.; Vousden, K.H. Coping with stress: Multiple ways to activate p53. Oncogene 2007, 26, 1306-1316. [CrossRef] [PubMed]

115. Scala, F.; Brighenti, E.; Govoni, M.; Imbrogno, E.; Fornari, F.; Trere, D.; Montanaro, L.; Derenzini, M. Direct relationship between the level of p53 stabilization induced by rrna synthesis-inhibiting drugs and the cell ribosome biogenesis rate. Oncogene 2016, 35, 977-989. [CrossRef] [PubMed]

116. Negi, S.S.; Brown, P. Transient rrna synthesis inhibition with CX-5461 is sufficient to elicit growth arrest and cell death in acute lymphoblastic leukemia cells. Oncotarget 2015, 6, 34846-34858. [CrossRef] [PubMed]

117. Negi, S.S.; Brown, P. Rrna synthesis inhibitor, CX-5461, activates atm/atr pathway in acute lymphoblastic leukemia, arrests cells in G2 phase and induces apoptosis. Oncotarget 2015, 6, 18094-18104. [CrossRef] [PubMed]

118. Campone, M.; Levy, V.; Bourbouloux, E.; Berton Rigaud, D.; Bootle, D.; Dutreix, C.; Zoellner, U.; Shand, N.; Calvo, F.; Raymond, E. Safety and pharmacokinetics of paclitaxel and the oral mtor inhibitor everolimus in advanced solid tumours. Br. J. Cancer 2009, 100, 315-321. [CrossRef] [PubMed]

119. Vlahovic, G.; Meadows, K.L.; Uronis, H.E.; Morse, M.A.; Blobe, G.C.; Riedel, R.F.; Zafar, S.Y.; Alvarez-Secord, A.; Gockerman, J.; Starodub, A.N.; et al. A phase I study of bevacizumab, everolimus and panitumumab in advanced solid tumors. Cancer Chemother. Pharmacol. 2012, 70, 95-102. [CrossRef] [PubMed]

120. Burgess, M.; Puhalla, S. BRCA 1/2-mutation related and sporadic breast and ovarian cancers: More alike than different. Front. Oncol. 2014, 4, 19. [CrossRef] [PubMed]

121. Harrison, S.J.; Khot, A.; Brajanovski, N.; Cameron, D.; Hein, N.; McArthur, G.A.; Lim, J.K.C.; O’Brien, S.; Ryckman, D.M.; Yu, G.I.; et al. A phase 1, open-label, dose escalation, safety, pk and pd study of a first in class pol1 inhibitor (CX-5461) in patients with advanced hematologic malignancies (HM). In Proceedings of the 2015 ASCO Annual Meeting, Chicago, IL, USA, 29 May-2 June 2015.

(C) 2017 by the authors; licensee MDPI, Basel, Switzerland. This article is an open access article distributed under the terms and conditions of the Creative Commons Attribution (CC BY) license (http:/ / creativecommons.org/licenses/by/4.0/). 